\title{
Review
}

\section{Anger and forgiveness: Resentment, generosity, and justice}

\author{
Martha Nussbaum \\ Oxford University Press, Oxford, 2016, 336pp., ISBN: 978-0199335879
}

Contemporary Political Theory (2018) 17, S9-S12. https://doi.org/10.1057/s41296-0170097-z; published online 24 February 2017

A wave of nationalistic populism is sweeping across Europe and North America. Some have concluded that anger is to blame for these developments (Moss, 2016). Others have asserted that those who want to resist the wave must tap into their anger for energy (Gambino, 2016). Given this, Martha Nussbaum's latest book, Anger and Forgiveness, is a timely meditation on the place of anger in our private and public lives. Her central claim is that anger is 'normatively problematic' in all spheres of human life, including the political. As Nussbaum has specified elsewhere, anger lies at the core of our current political predicaments (Green, 2016), but it is certainly not part of her solution.

Drawing on what she describes as a long tradition of philosophical and political thought - which counts Aristotle and the Stoics among its members - Nussbaum proposes a simple definition of anger. She maintains that anger consists of two intrinsic components: the idea that a serious wrong has been committed, and a wish for the wrongdoer to suffer (pp. 5, 15). The problems with anger stem from the second component, namely, the desire for retribution. This desire is unjustifiable, according to Nussbaum. Either it puts us on the 'road to payback,' which involves the irrational belief that taking revenge on an offender can restore what the offense damaged. Alternatively, we end up on the 'road to status.' This entails the perception that the offense has resulted in a lowering of relative status that can only be restored by undermining the status of the offender. Here, retribution can be reasonable insofar as one can indeed raise one's status relative to someone else by lowering the status of this person (pp. 5-6). Such a desire demonstrates an excessive concern with relative status - Nussbaum calls it 'a narcissistic error' which should be discouraged. The reason for this, I infer, is because it conflicts with the core liberal commitment to the equal dignity of human beings (pp. 38, 200).

Despite the intrinsic faults of anger, Nussbaum concedes that it can have three constructive functions, provided that the perceived harm is well-grounded - i.e., if there is clear evidence that the subject of anger has intentionally inflicted serious

(c) 2017 Macmillan Publishers Ltd. 1470-8914 Contemporary Political Theory Vol. 17, S1, S9-S12 
damage (p. 35). First, anger can signal to oneself and others that a wrong has occurred, although its trustworthiness in this role is questionable given its narcissistic bias. Second, anger can provide the motivation to take action against the cause of a wrong. Finally, anger may deter others from causing damage in the future by warning them of the negative consequences of harmful acts (pp. 5-6, 38-39). The efficacy of anger as a deterrent, however, has less to do with the subjective emotion than with its visible expression. Indeed, Nussbaum says that it is much preferable to give a controlled performance of angry behavior than to actually be angry (pp. 141, 153).

One important caveat to her denunciation of the fiery emotion is what Nussbaum dubs 'Transition-anger.' The term 'Transition' describes what she deems the rational person's response to anger. This involves extricating oneself from the emotion and its preoccupation with the past by recognizing its normative problems and, instead, adopting a forward-looking focus on welfare (pp. 31, 93). Confusing matters somewhat, Nussbaum uses Transition to refer to both the process of transitioning from anger to a forward-looking mentality concerned with welfare, as well as this mentality itself (p. 33). The compound of Transition and anger is a combination of a forward-looking focus on welfare and anger's recognition of wrongfulness. As Nussbaum explains it, the entire content of Transition-anger is: 'How outrageous. Something should be done about that.' Since it lacks the desire for payback essential to anger, we should actually understand Transition-anger as a particular emotion distinct from 'garden-variety' anger (pp. 35, 141).

Pure Transition-anger, according to Nussbaum, is very rare. Parents might experience it in relation to their children, particularly young ones, when they misbehave. In such cases, the anger of the parents may consist in the recognition of the wrong accompanied by a desire to help the child (p. 105). In the political sphere, Nussbaum suggests that the Civil Rights Movement was, at certain points, driven by Transition-anger. Nevertheless, Transition-anger must be handled with care. Most of the time, it contains at least some residue of anger's destructive wish for payback. Even when we say that we are outraged about the violation of some principle and want to prevent this in the future, we often begin to want the particular violator to suffer (pp. 36-37). So while anger can potentially be constructive, Nussbaum urges us to avoid it whenever possible.

More controversially perhaps, Nussbaum also argues that forgiveness, popularly seen as the morally superior alternative to anger, is equally problematic in most cases. According to Nussbaum, the most common type of forgiveness is transactional, involving an exchange of apology for forgiveness. Nussbaum traces this to the strand of the Christian tradition that emphasizes confession and apology (chap. 2). In this form, forgiveness suffers from the same intrinsic flaw as anger, that is, the desire for the wrongdoer to suffer, in this case through some self-abasing act of contrition (p. 74). 
She proposes two alternatives to transactional forgiveness that we should reach for when we are angry: unconditional forgiveness, and unconditional love and generosity. The first option, at least in practice, eschews the demand for apology and other acts of penance. Instead the wronged person grants forgiveness out of her own 'free choice' (pp. 11-12). While unconditional forgiveness might be preferable to transactional forgiveness, Nussbaum is still wary of it. Unconditional forgiveness 'retains a whiff of moral superiority,' and it is also too focused on the past. Therefore, it does not reliably guide us to the forward-looking attitude of Transition (pp. 77, 124, 141). The ideal response to anger, according to Nussbaum, is unconditional love. This is when 'love simply drowns out' anger, so that the question of whether one should forgive is never posed (p. 84).

To illustrate the pitfalls of anger as well as forgiveness, Nussbaum examines a range of examples from philosophy, law, literature, religion, and the history of political movements. [There are also amusing examples from her own life involving anonymous Nobel Prize winners behaving like children (chap. 5)]. The analysis of political movements (chap. 7), which focuses on Mahatma Gandhi, Martin Luther King, and Nelson Mandela, is particularly interesting considering recent events, but it also presents some problems for Nussbaum's thesis. According to Nussbaum, these great leaders of the twentieth century agree with her argument that in politics as in other spheres of life, anger is destructive because it involves preoccupation with the past (pp. 221, 230). She acknowledges that King and Mandela occasionally drew on anger, but in those cases it was either Transitionanger without a desire for retribution, or regular anger quickly succeeded by Transition (p. 212). While this might be true, the evidence presented does not seem to support Nussbaum's stronger claim that King and Mandela would agree that anger is 'politically futile' (p. 236). For instance, Nussbaum quotes from Mandela's book, The Long Walk to Freedom:

I had no epiphany, no singular revelation, no moment of truth, but a steady accumulation of a thousand slights, a thousand indignities and a thousand unremembered moments produced in me an anger, a rebelliousness, a desire to fight the system that imprisoned my people (Mandela, 1994, p. 109).

Nussbaum interprets this as an instance of moving from anger, and its desire for retribution, to Transition (pp. 227-228). But these words (or the passage in which they appear) do not show clearly that Mandela thought he had given up his anger, even if he had abandoned any conscious desire for retribution. A more straightforward interpretation could be that he saw himself as channeling his anger productively. King, similarly - as Nussbaum (pp. 212, 221-222) demonstrates - perceived a politically constructive role for anger, as long as it was not channeled toward vengeance. Even if King and Mandela agreed with Nussbaum

(C) 2017 Macmillan Publishers Ltd. 1470-8914 Contemporary Political Theory Vol. 17, S1, S9-S12 S11 
that the desire for retribution is constitutive of anger (which is questionable), they evidently did not believe that it was a fatal problem.

What the examples of King and Mandela seem to demonstrate is that it is indeed possible to experience 'real' anger and use it politically, without acting on the wish for payback. Hence, one wonders whether it is worth obsessing over any residual payback wish in Transition-anger and unconditional forgiveness, especially since such residue could be present in any emotion or action. Moreover, if anger can enable activists to resist the present turn towards illiberalism, the principal task of the political theorist is, surely, not to police their emotions, but to provide them with resources for constructive resistance.

Although Nussbaum's attempt to delegitimize anger is not entirely convincing, her exposition is a thought-provoking contribution to scholarly debates on anger and its role in politics. Her writing, as always, is erudite and engaging, and she uses it to craft a sharp lens through which students of politics can interpret current events. Advanced undergraduates and scholars of political emotions will find this to be an important resource and starting point for discussion - possibly quite heated, however much Nussbaum might prefer the temperature to be kept down.

\section{References}

Gambino, L. (2016) Resistance and anger: progressives urge Democratic party to stand up and fight. Guardian, 12 November. https://www.theguardian.com/us-news/2016/nov/12/democrats-dnc-partychair-progressives-ellison-dean-omalley, accessed 17 January 2017.

Green, E. (2016) The anger of the American people. The Atlantic, 7 May. http://www.theatlantic.com/ politics/archive/2016/05/martha-nussbaum-anger/481464/, accessed 17 January 2017.

Mandela, N (1994). Long Walk to Freedom. London: Abacus.

Moss, P. (2016) 2016: The year of anger. BBC News, [online] 31 December. http://www.bbc.co.uk/news/ world-38460516, accessed 3 January 2017.

Dan Degerman

Lancaster University, Lancaster LA1 4YH, UK 